\title{
A revision of genus Xerobion Nevsky, 1928 (Homoptera: Aphididae)
}

\section{Ревизия тией рода Xerobion Nevsky, 1928 (Homoptera: Aphididae)}

\author{
R.Kh. Kadyrbekov \\ P.X. Кадырбеков
}

\begin{abstract}
Institute of Zoology Ministry of Education and Sciences of Kazakhstan Republic, Academgorodok, Al-Farabi av., 93, Almaty 050060, Kazakhstan, E-mail: rustem61@inbox.ru

Институт зоологии Министерства образования и науки Республики Казахстан, Академгородок, проспект Аль Фараби, 93, Алматы 050060, Казахстан.
\end{abstract}

KEY WORDS: Aphids, Xerobion, revision, new species, key.

КЛЮЧЕВЫЕ СЛОВА: тли, Xerobion, ревизия, определительный ключ.

ABSTRACT. Aphids from the genus Xerobion Nevsky, 1928 has been revised to include 18 species. Three new species from the Kazakhstan are described: X. barsukense Kadyrbekov sp.n. from Helichrysum arenarium, X. compositae Kadyrbekov sp.n. from Cousinia perovskiensis and Cirsium arvense, $X$. desertorum Kadyrbekov sp.n. from Helichrysum arenarium. New synonyms are installed. X. artemisiae (Narzikulov, 1949), X. terraealbae Ivanovskaja, 1959) are new synonyms of the $X$. cinae (Nevsky, 1928). X. brutii (Barbagallo, 1996), X. georgii (Mier et Nieto, 1991) are new synonyms of the $X$. caspicae (Bozhko, 1963). X. tashevella (Eastop et Hille Ris Lambers, 1976) is new synonym of the $X$. lambersi (Taschev, 1961) stat. rest. Key to apterous viviparous females of all known species Xerobion is compiled.

РЕЗЮМЕ. Проведена ревизия тлей рода Xerobion Nevsky, 1928, включающего 18 видов. Описаны три новых вида из Казахстана: X. barsukense Kadyrbekov sp.n. с бессмертника (Helichrysum arenarium), который близок к X. camphorosmae (Taschev, 1961), но отличается от него соотношениями шпица к основанию шестого членика усиков $(0,75-1,00$ против 0,9 $1,2)$, трубочек к хвостику $(0,59-0,65$ в сравнении с $0,45-0,55)$, хвостика ко второму членику задней лапки $(1,0-1,1$ против $0,83-0,98)$ и иным растениемхозяином.

$X$. compositae Kadyrbekov sp.n. с кузинии (Cousinia perovskiensis) и бодяка (Cirsium arvense), который близок к X. lambersi (Taschev, 1961) по отсутствию воскового налёта на теле и соотношению последнего членика хоботка и второго членика задней лапки, но отличается пропорцией третьего членика усиков к шестому $(1,0-1,4$ в сравнении с $0,7-1,0)$, более длинными лобными волосками, цветом бёдер (на препаратах) и иным растением-хозяином.

$X$. desertorum Kadyrbekov sp.n. с бессмертника (Helichrysum arenarium), который близок к X. alakuli
(Juchnevitsh, 1974) по длинным лобным волоскам, но отличается по форме хвостика, его соотношению с длиной тела $(0,045-0,053$ в сравнении с $0,055-$ $0,065)$ и иным растением-хозяином.

Установлены новые синонимы. X. artemisiae (Narzikulov, 1949), X. terraealbae Ivanovskaja, 1959) - новые синонимы $X$. cinae (Nevsky, 1928). X. brutii (Barbagallo, 1996), X. georgii (Mier et Nieto, 1991) новые синонимы $X$. caspicae (Bozhko, 1963). $X$. tashevella (Eastop et Hille Ris Lambers, 1976) — новый синоним $X$. lambersi (Taschev, 1961) stat.rest. Coставлен определительный ключ по бескрылым живородящим самкам всех известных видов Xerobion.

\section{Introduction}

Xerobion is the South Palaearctic genus with 18 species in world fauna [Blackman \& Eastop, 2006; Kadyrbekov, 2001; G. \& M. Remaudière, 1997]. This genus includes 3 species on Chenopodiaceae: X. camphorosmae (Taschev, 1961), X. eriosomatinum Nevsky, 1928, X. juchnevitchae Smajlova, 1974 initially. Later subgenus Absinthaphis Remaudière et Stary, 1973 (genus Aphis) on Asteraceae was synonymized with Xerobion [Kadyrbekov, 2001]. Now Xerobion includes species with short volcano-shaped siphunculi and triangular cauda. All of them are narrow oligophagous or monophagous on plants of the Asteraceae and Chenopodiaceae in the arid zone of the Palearctic.

\section{Materials and methods}

We studied the types of Xerobion artemisiae (Narzikulov, 1949), X. cinae (Nevsky, 1928), X hirsutum (Nevsky, 1929), X. terraealbae (Ivanovskaja, 1959) from the collection of the Zoological Institute RAN (Saint-Petersburg, Russia) and paratypes of $X$. caspicae (Bozhko, 1963), X. inthybi Bozhko, 1963 from the collection of Bozhko (Kharkov, Ukraine). Type series 
of X. alakuli (Juchnevitsh, 1974), X. juchnevitchae Smajlova, 1974 are stored in the collection of the Institute of Zoology on Republic of Kazakhstan (Almaty). Paratypes of X. album (Remaudière et Davatchi, 1959), $X$. georgii (Mier et Nieto, 1991), X. judenkoi (Szelegiewicz, 1959), X. hortobagyi (Szelegiewicz, 1978), $X$. pannonica (Szelegiewicz, 1978) has kindly sent by the Remaudière (Museum national d'Histoire naturelle, Paris, France). Besides, a lot of specimens $X$. alakuli (Juch.), X. cinae (Nevs.), X. camphorosmae (Tasch.),
$X$. eriosomatinum Nevs., $X$. caspicae (Bozh.), X. lambersi (Tasch.), X. judenkoi (Szel.), X. pannonica (Szel.) from the collection of Institute of Zoology on Republic of Kazakhstan (Almaty) have also been studied. Original descriptions [Barbagallo, 1996; Bozhko, 1963; Ivanovskaja, 1960; Mier Durante \& Nieto Nafria, 1991; Nevsky, 1929, 1937; Juchnevitsh, 1974; Garcia Prieto \& Sanchis Segovia, 1998; Remaudière \& Davatchi, 1959; Smajlova, 1974; Szelegiewicz, 1959, 1978; Taschev, 1961] of all the known species have been studied also.

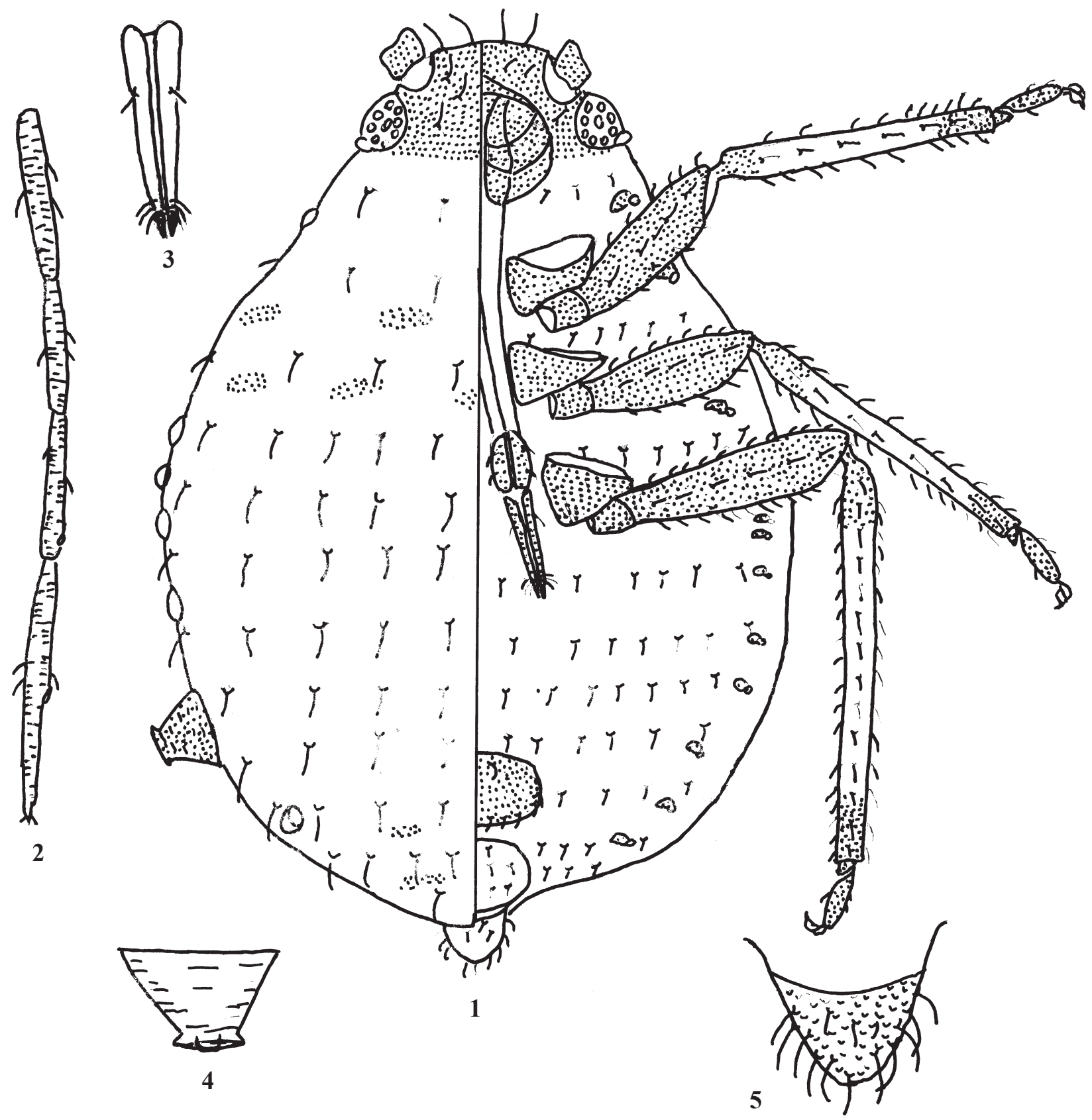

Figs 1-5. Xerobion barsukense Kadyrbekov sp.n., apterous viviparous female: 1 — habitus; 2 — III-VI antennal segments; 3 - ultimate rostral segment; 4 - siphunculus; 5 - cauda.

Рис. 1-5. Xerobion barsukense Kadyrbekov sp.n., бескрылая живородящая самка: 1 — габитус; 2 - III-VI членики усиков; 3 последний членик хоботка; 4 - трубочки; 5 - хвостик. 
Form of ultimate rostral segment, number of marginal tubercles, natural color, color on slides, presence or absence of wax powder and secondary rhinariae, long of frontal hairs, number of hairs on cauda and $8^{\text {th }}$ tergite, the ratios of $3^{\text {rd }}$ antennal segment to $6^{\text {th }}$ one and processus terminalis, processus terminalis to the base of $6^{\text {th }}$ antennal segment, ultimate rostral segment to second segment of hind tarsus, siphunculi to body and cauda, cauda to body and second segment of hind tarsus are used for the preparation of key to all known species.

Holotypes and paratypes of described taxa are deposited in the collection of Institute of Zoology (Almaty, Kazakhstan). Part of paratypes is kept in the Zoological Institute of RAN (Saint-Petersburg, Russia).

All measurements are given in millimeters.

\section{Results}

\section{Xerobion barsukense Kadyrbekov sp.n.} Figs. 1-5

TYPE MATERIAL. Holotype: 1 apterous viviparous female, slide No 1874, Helichrysum arenarium, South-West Kazakhstan, Aral region, Big Barsuki desert, $90 \mathrm{~km}$ to South Chelkar town, 06.06.1990, R.Kh. Kadyrbekov; paratypes: 2 apterous viviparous females together with holotype.

DIAGNOSIS. New species relates to $X$. camphorosmae (Taschev, 1961). It differs by having the ratios of processus terminalis to the base of $6^{\text {th }}$ antennal segment $(0.75-1.00$ versus $0.90-1.20)$, siphunculi to cauda $(0.59-0.65$ in comparison $0.45-0.55)$, cauda to the second segment of hind tarsus (1.00-1.10 against 0.83-0.98) and other host plant.

Apterous viviparous female (by the 3 specimens). Body broad oval, 1.38-1.52 (Fig. 1). Cuticle reticulated. Frons convex. Frontal setae (0.039-0.045) 2.3-3.0 of basal diameter of $3^{\text {rd }}$ antennal segment. Antennae six-segmented, 0.48 0.50 of body length. Third segment $1.5-1.6$ of $4^{\text {th }}, 1.6-2.0$ of processus terminalis and $0.76-0.86$ of $6^{\text {th }}$ segment. Processus terminalis $0.75-1.0$ of base of $6^{\text {th }}$ segment (Fig. 2). Fourth segment $0.83-0.92$ of $5^{\text {th }}$. Secondary rhinariae are absent. Hairs on $3^{\text {rd }}$ segment $(0.011-0.017) 0.8-1.0$ of its basal diameter. Clypeus normal, rostrum reaches behind to middle coxae. Ultimate rostral segment (Fig. 3) elongated, $1.50-1.65$ of second segment of hind tarsus, with 2 accessory hairs. Siphunculi short, volcano-shaped with flanges, about $0.047-0.056$ of body length, $0.59-0.65$ of cauda length, $0.66-0.75$ of its maximal width, $0.63-0.66$ of second segment of the hind tarsus (Fig.4). Cauda triangular, $0.080-0.086$ of body length, $0.85-0.92$ of its basal width, $1.00-1.06$ of second segment of hind tarsus, with 12-16 hairs (Fig. 5). Marginal tubercles gentle, hemispherical, developed on prothorax, $1^{\text {st }}-4^{\text {th }}$ and $7^{\text {th }}$ tergites. Diameter of tubercle on $7^{\text {th }}$ tergite $(0.017) 0.6-0.7$ of $1^{\text {st }}$ one and 1.2 of basal diameter of $3^{\text {rd }}$ antennal segment. Hairs on 3-6 tergites (0.039-0.045) $2.3-3.0$ of basal diameter of $3^{\text {rd }}$ antennal segment. $8^{\text {th }}$ tergite with $2-3$ hairs. Genital plate oval with $2-3$ hairs on disc and 10-12 ones along its posterior margin. Legs normally developed. Trochanter hair of the hind leg (0.034-0.039) $0.75-0.85$ and longest hair on the external side of hind femur $(0.022-0.028) 0.45-0.65$ of trochantrofemoral suture. First tarsal segments with 3:3:2 hairs.

Color on slide: head, $1^{\text {st }}, 2^{\text {nd }}, 5^{\text {th }}, 6^{\text {th }}$ antennal segments, clypeus, $3^{\text {rd }}-4^{\text {th }}$ segments of rostrum, coxae, trochanters, fem- ora, bases and apices of tibiae, tarsi, genital plate, dorsal spots and stripes on pro-, meso-, metathorax, $4-5^{\text {th }}, 7-8^{\text {th }}$ tergites brownish; siphunculi brown; cauda pale or light brownish.

Natural coloration: body dark-brown with wax powder; eyes dark-reddish; siphunculi blackish).

Measurement of holotype. Body 1.52; antennae 0.740.75: III 0.18, IV 0.12, V 0.13, VI 0.21-0.22 (0.12+0.090.10 ); siphunculi $0.078 / 0.117,0.078 / 0.104$; cauda $0.12 / 0.14$; ultimate rostral segment 0.169 ; second segment of hind tarsus 0.117 .

HOST PLANT. Helichrysum arenarium (L.) Moench. (Asteraceae).

BIONOMY. Aphids suck on flowers and shoots, visited by ants.

ETYMOLOGY. The name of species is derived from name of sandy desert where it was collected.

\section{Xerobion compositae Kadyrbekov sp.n.} Figs 6-10

TYPE MATERIAL. Holotype: 1 apterous viviparous female, No940, Cousinia perovskiensis, Southern Kazakhstan, Zhambil Area, Western Tien-Shan, Karatau ridge, $10 \mathrm{~km}$ to South-West Zhanatas town, Ushbas river, H-600 m., 22.05.1988, R.Kh. Kadyrbekov; paratypes: 2 apterous viviparous females together with holotype, 9 oviparous females, slide No 134 (old series), Cirsium arvense, Central Kazakhstan, Karaganda Area, Zhanaarka district, Koksengir mountains, Taldymanak river, 17.09.1962, N.E. Smajlova.

DIAGNOSIS. New species is closed to $X$. lambersi (Taschev, 1961) by absence wax powder on the body and ratio of ultimate rostral segment to second segment of hind tarsus. It differs from this species by the proportion of third to six antennal segments (1.0-1.4 versus $0.7-1.0)$, mor long frontal hairs, color of femora (in slides) and other host plant.

Apterous viviparous female (by 3 specimens). Body broad oval, 1.48-1.63 (Fig. 6). Cuticle reticulated. Frons convex. Frontal setae $(0.034-0.045) 2.0-2.5$ of basal diameter of $3^{\text {rd }}$ antennal segment. Antennae six-segmented, 0.43-0.49 of body length. Third segment $1.5-1.9$ of $4^{\text {th }}, 2.9-3.5$ of processus terminalis and $1.0-1.25$ of $6^{\text {th }}$ segment. Processus terminalis $0.5-0.7$ of base of $6^{\text {th }}$ segment (Fig. 7). Fourth segment $0.95-1.10$ of $5^{\text {th }}$. Secondary rhinariae are on $3^{\text {rd }}(5-8), 4^{\text {th }}(2-$ $3), 5^{\text {th }}(0-1)$ antennal segments. Hairs on $3^{\text {rd }}$ segment $(0.017)$ equal to its basal diameter. Clypeus normal, rostrum reaches to middle coxae. Ultimate rostral segment (Fig. 8) stilettoshaped 1.0-1.1 of second segment of hind tarsus, with 2 accessory hairs. Siphunculi very short, volcano-shaped with flanges, about $0.040-0.044$ of body length, $0.65-0.71$ of cauda length, $0.68-0.71$ of its maximal width, $0.54-0.56$ of second segment of the hind tarsus (Fig. 9). Cauda triangular, $0.47-0.64$ of its basal width, $0.77-0.85$ of second segment of hind tarsus, with 19-22 hairs (Fig. 10). Marginal tubercles gentle, hemispherical, developed on prothorax, $1^{\text {st }}$ and $7^{\text {th }}$ tergites. Diameter of tubercle on $7^{\text {th }}$ tergite $(0.022-0.028)$ $0.5-0.7$ of $1^{\text {st }}$ one and $1.0-1.2$ of basal diameter of $3^{\text {rd }}$ antennal segment. Hairs on 3-6 tergites (0.028-0.034) 1.7-2.0 of basal diameter of $3^{\text {rd }}$ antennal segment. $8^{\text {th }}$ tergite with 4-8 hairs. Genital plate oval with 2 hairs on disc and 6-7 ones along its posterior margin. Legs normally developed. Trochanter hair of the hind leg (0.034-0.045) $0.73-0.75$ and longest hair on the external side of hind femur (0.028-0.039) $0.62-0.64$ of trochantro-femoral suture. First tarsal segments with $3: 3: 2$ hairs.

Color on slide: head, $1^{\text {st }}, 2^{\text {nd }}, 6^{\text {th }}$ antennal segments, clypeus, $3^{\text {rd }}-4^{\text {th }}$ segments of rostrum, coxae, trochanters, femora, apices of tibiae, tarsi, genital plate, dorsal spots on 
pro-, meso-, metathorax light brownish; siphunculi brown; cauda pale.

Natural coloration: body dark-green without wax powder; eyes dark-reddish; siphunculi blackish.

Measurements of holotype. Body 1.61; antennae 0.70 0.73: III $0.20-0.21$, IV $0.11-0.12$, V $0.10-0.12$, VI 0.17 (0.10-0.11+0.06-0.07); siphunculi 0.065/0.091, 0.065/0.091; cauda $0.10 / 0.156$; ultimate rostral segment 0.13 ; second segment of hind tarsus 0.117 .

Oviparous female (by 9 specimens). Body broad oval, 1.81-1.96. Antennae six-segmented, $0.48-0.56$ of body length. Third segment 3.1-3.9 of processus terminalis and $1.2-1.4$ of $6^{\text {th }}$ segment. Secondary rhinariae are only on $3^{\text {rd }}$ $(0-1)$ antennal segments. Ultimate rostral segment $0.9-1.0$ of second segment of hind tarsus. Siphunculi about 0.70
0.75 of cauda length. Genital plate oval with 6-12 hairs on disc and 12-22 ones along its posterior margin. Hind tibiae with 100-150 pseudosensoriae. Other characters as apterous female.

Color on slide: head, $1^{\text {st }}, 2^{\text {nd }}, 6^{\text {th }}$ antennal segments, clypeus, $3^{\text {rd }}-4^{\text {th }}$ segments of rostrum, coxae, trochanters, femora, apices of tibiae, tarsi, genital plate, dorsal spots on pro-, meso-, metathorax light brownish; siphunculi brown; cauda pale.

HOST PLANT. Cirsium arvense (L.) Scop., Cousinia perovskiensis (Bornm.) Juz. (Asteraceae).

BIONOMY. Aphids suck on the lower side of leafs, visited by ants.

ETYMOLOGY. The name of species is derived from name of sandy desert where it was collected.

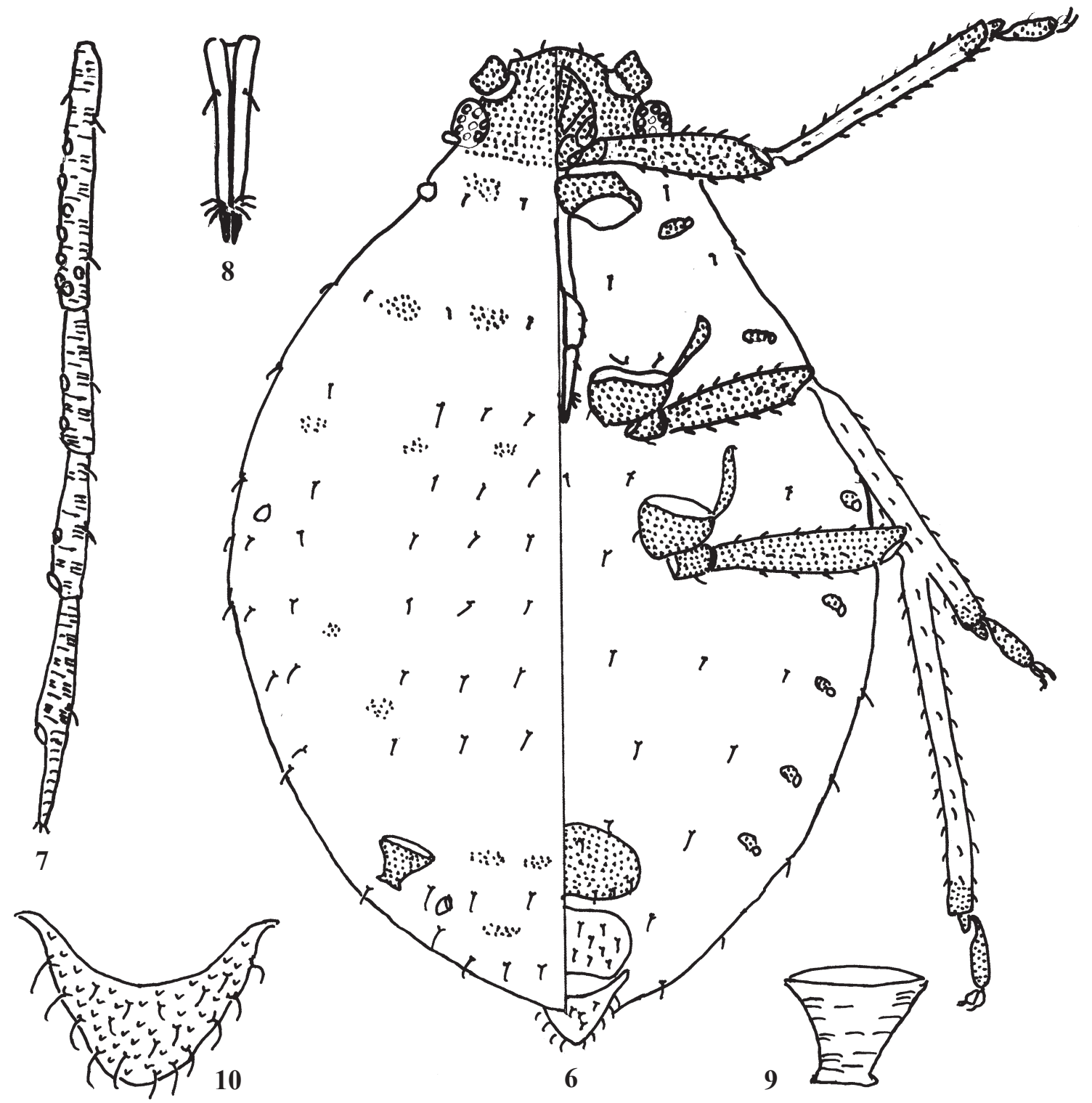

Figs 6-10. Xerobion compositae Kadyrbekov sp.n., apterous viviparous female: 6 - habitus; 7 - III-VI antennal segments; 8 ultimate rostral segment; 9 - siphunculus; 10 - cauda.

Рис. 6-10. Xerobion compositae Kadyrbekov sp.n., бескрылая живородящая самка: 6 - габитус; 7 - III-VI членики усиков; 8 последний членик хоботка; 9 - трубочки; $10-$ хвостик. 
Xerobion desertorum Kadyrbekov sp.n. Figs 11-15

TYPE MATERIAL. Holotype: 1 apterous viviparous female, slide No 1876, Helichrysum arenarium, South-West Kazakhstan, Aral region, Big Barsuki desert, $90 \mathrm{~km}$ to South Chelkar town, 06.06.1990, R.Kh. Kadyrbekov; paratypes: 6 apterous viviparous females together with holotype.

Diagnosis. A new species is closed to $X$. alakuli (Juchnevitsh, 1974) by long of frontal hairs. It differs by the shape of cauda, its proportion to the body length $(0.045-0.053$ against 0.055-0.065) and other host plant.

Apterous viviparous female (by 7 specimens). Body oval, 0.99-1.22 (Fig. 11). Cuticle reticulated. Frons convex. Frontal setae (0.028-0.039) 2.5-3.5 of basal diameter of $3^{\text {rd }}$ antennal segment. Antennae five-, six-segmented, $0.35-0.42$ of body length. Third segment $1.75-2.15$ of $4^{\text {th }}$,
$1.5-2.8$ of processus terminalis and $0.65-1.05$ of $6^{\text {th }}$ segment. Processus terminalis $0.50-0.75$ of base of $6^{\text {th }}$ segment (Fig. 12). Fourth segment $0.7-1.0$ of $5^{\text {th }}$. Secondary rhinariae are on $3^{\text {rd }}(0-2), 4^{\text {th }}(0-1)$ antennal segments. Hairs on $3^{\text {rd }}$ segment (0.011-0.017) 1.0-1.5 of its basal diameter. Clypeus normal, rostrum reaches to middle coxae. Ultimate rostral segment (Fig. 13) stiletto-shaped, 1.25-1.37 of second segment of hind tarsus, with 2 accessory hairs. Siphunculi very short, volcano-shaped with flanges, about $0.032-0.039$ of body length, $0.60-0.75$ of cauda length, $0.43-0.60$ of its maximal width, 0.43 of second segment of the hind tarsus (Fig. 14). Cauda bluntly triangular, 0.045-0.053 of body length, $0.45-0.55$ of its basal width, $0.57-0.71$ of second segment of hind tarsus, with 8-10 hairs (Fig. 15). Marginal tubercles gentle, hemispherical, developed on prothorax, $1^{\text {st }}$ and $7^{\text {th }}$ tergites. Diameter of tubercle on $7^{\text {th }}$ tergite $(0.017-$

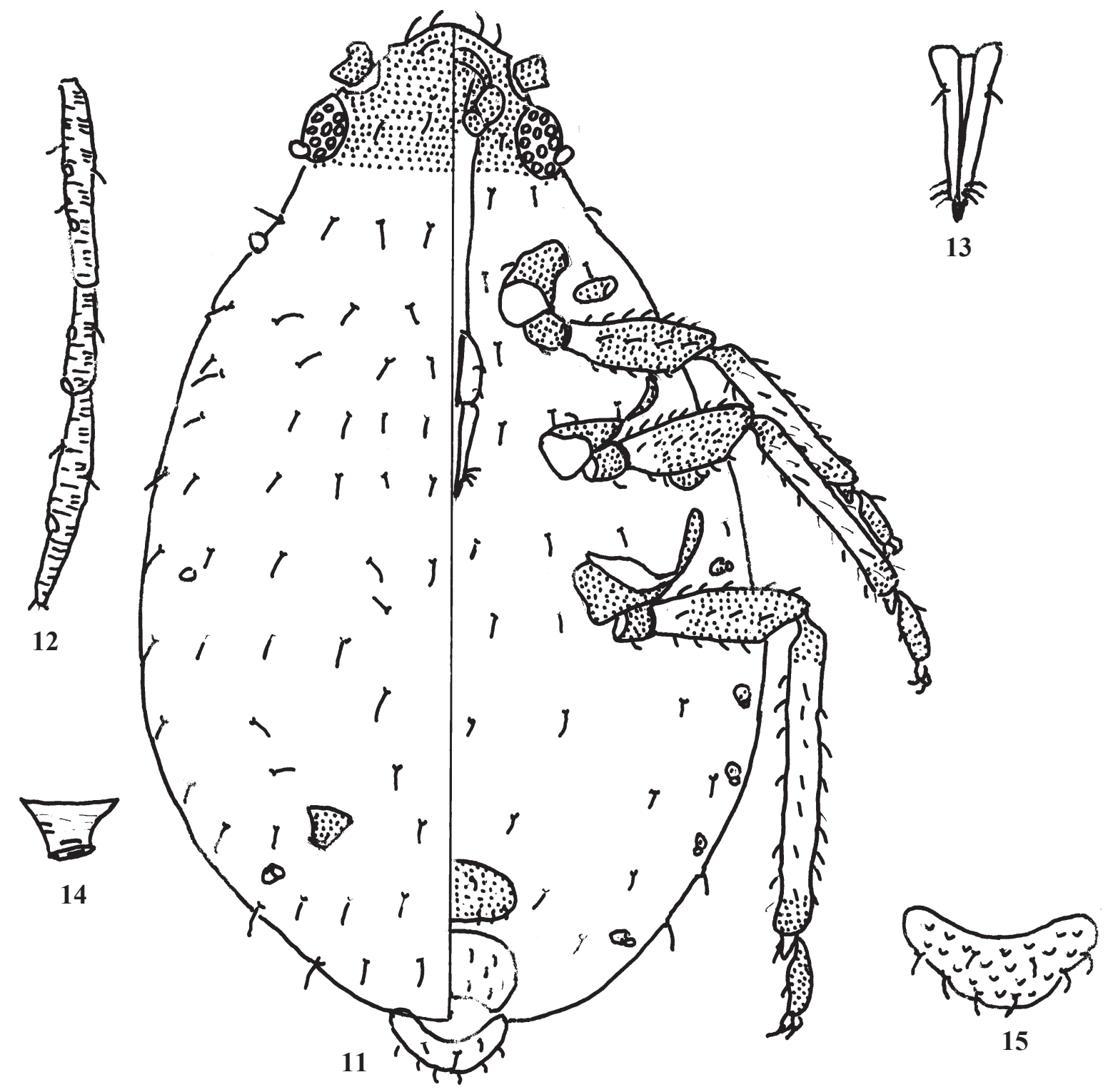

Figs 11-15. Xerobion desertorum Kadyrbekov sp.n., apterous viviparous female: 11 — habitus; 12 - III-VI antennal segments; 13 ultimate rostral segment; 14 - siphunculus; 15 - cauda.

Рис. 11-15. Xerobion desertorum Kadyrbekov sp.n., бескрылая живородящая самка: 11 - габитус; 12 - III-VI членики усиков; 13 - последний членик хоботка; 14 - трубочки; 15 - хвостик. 
$0.020) 0.77-1.0$ of $1^{\text {st }}$ one and $1.2-1.7$ of basal diameter of $3^{\text {rd }}$ antennal segment. Hairs on $3-6$ tergites $(0.034-0.039)$ $2.8-3.5$ of basal diameter of $3^{\text {rd }}$ antennal segment. $8^{\text {th }}$ tergite with 4-7 hairs. Genital plate oval with 2 hairs on disc and 56 ones along its posterior margin. Legs normally developed. Trochanter hair of the hind leg $(0.028-0.034) 0.65-0.80$ and longest hair on the external side of hind femur $(0.022$ 0.028 ) $0.50-0.65$ of trochantro-femoral suture. First tarsal segments with $3: 3: 2$ hairs.

Color on slide: head, $1^{\text {st }}, 2^{\text {nd }}, 6^{\text {th }}$, apices of $5^{\text {th }}$ antennal segments, clypeus, $3^{\text {rd }}-4^{\text {th }}$ segments of rostrum, coxae, trochanters, femora (besides the bases), bases and apices of tibiae, tarsi, genital plate, dorsal spots on pro-, meso-, metathorax, siphunculi brown; cauda pale.

Natural coloration: body dark-green without wax powder; eyes dark-reddish; siphunculi blackish.

Measurements of holotype. Body 1.22; antennae 0.44 0.45: III 0.091, IV $0.052-0.065$, V 0.078 , VI $0.13-0.14$ (0.08+0.05-0.06); siphunculi 0.039/0.065; cauda 0.065/0.117; ultimate rostral segment 0.117 ; second segment of hind tarsus 0.091

HOST PLANT. Helichrysum arenarium (L.) Moench. (Asteraceae).

BIONOMY. Aphids suck on flowers and shoots, visited by ants.

Xerobion cinae (Nevsky, 1928)

$=X$. artemisiae (Narzikulov, 1949) syn. $\mathbf{n}$.

$=X$. terraealbae (Ivanovskaja, 1959) syn. n.

REMARKS. We have studied type slides of $X$. artemisiae and $X$. terraealbae (Table 1 ). Values of morphological characters from Table 1 have almost complete overlap in fact. Thus, $X$. artemisiae, $X$. terraealbae living on the plants of Seriphidium subgenus from Artemisia genus are new synonyms of $X$. cinae. $X$. hirsutum (Nevsky, 1929) is described erroneously by the larvae of some older of Protaphis species. Alate viviparous females on the same slides aren't differs from alate viviparous females of $X$. cinae. Thus, $X$. hirsutum should be moved into the genus Protaphis Börner, 1952.

Apterous viviparous female (by specimens from type series and materials from Kazakhstan). Body oval, 1.221.82. Cuticle reticulated. Frons convex. Frontal setae (0.031$0.039) 1.6-2.3$ of basal diameter of $3^{\text {rd }}$ antennal segment. Antennae six-segmented, $0.31-0.46$ of body length. Third segment $1.3-2.0$ of $4^{\text {th }}, 1.7-2.5(2.8)$ of processus terminalis and $0.7-1.0$ of $6^{\text {th }}$ segment. Processus terminalis $0.55-0.70$ of base of $6^{\text {th }}$ segment. Fourth segment $0.9-1.0$ of $5^{\text {th }}$. Secondary rhinariae are on $3^{\text {rd }}(0-5), 4^{\text {th }}(0-2), 5^{\text {th }}(0-1)$ antennal segments. Hairs on $3^{\text {rd }}$ segment $(0.008-0.014) 0.6-1.0$ of its basal diameter. Clypeus normal, rostrum reaches behind to middle coxae. Ultimate rostral segment stiletto-shaped, 1.201.45 of second segment of hind tarsus, with 2 accessory hairs. Siphunculi very short, volcano-shaped with flanges, about $0.033-0.043$ of body length, $0.50-0.85$ of cauda length, $0.5-$ 0.8 of its maximal width, $0.48-0.63$ of second segment of the hind tarsus. Cauda triangular, $0.42-0.75$ of its basal width, 0.6-1.1 of second segment of hind tarsus, with 14-22 hairs. Marginal tubercles gentle, hemispherical, developed on prothorax, $1^{\text {st }}$ and $7^{\text {th }}$ tergites. Diameter of tubercle on $7^{\text {th }}$ tergite (0.039-0.050) $1.2-1.4$ of $1^{\text {st }}$ one and $2.0-2.5$ of basal diameter of $3^{\text {rd }}$ antennal segment. Hairs on 3-6 tergites $(0.022-$ $0.028) 1.3-1.7$ of basal diameter of $3^{\text {rd }}$ antennal segment. $8^{\text {th }}$ tergite with 4-6 hairs. Genital plate oval with 2-3 hairs on disc and 5-9 ones along its posterior margin. Legs normally developed. Trochanter hair of the hind leg (0.034-0.039) $0.75-0.85$ and longest hair on the external side of hind femur $(0.022-0.028) 0.45-0.65$ of trochantro-femoral suture. First tarsal segments with $3: 3: 2$ hairs.

Color on slide: head, $1^{\text {st }}, 2^{\text {nd }}, 5^{\text {th }}, 6^{\text {th }}$ antennal segments, clypeus, $3^{\text {rd }}-4^{\text {th }}$ segments of rostrum, coxae, trochanters, femora, bases and apices of tibiae, tarsi, genital plate, dorsal spots and stripes on pro-, meso-, metathorax, $4-5^{\text {th }}, 7-8^{\text {th }}$ tergites brownish; siphunculi brown; cauda pale or light brownish.

Natural coloration: body dark-green or green-brownish with wax powder; eyes dark-reddish; siphunculi blackish.

Alate viviparous female (by 6 specimens). Body oval, 1.26-1.53. Antennae $0.51-0.56$ of body length. Third antennal segment $1.75-2.0$ of $4^{\text {th }}, 1.05-1.35$ of $6^{\text {th }}, 2.6-3.7$ of processus terminalis. Fourth antennal segment $0.9-1.1$ of $5^{\text {th }}$. Secondary rhinariae are on $3^{\text {rd }}(5-11), 4^{\text {th }}(1-4), 5^{\text {th }}(0-1)$ antennal segments. Siphunculi about $0.55-1.00$ of cauda. Other characters as apterous female.

Color on slide: head, thorax, antennae, clypeus, $3^{\text {rd }}-4^{\text {th }}$ segments of rostrum, coxae, trochanters, femora, bases and apices of tibiae, tarsi, genital plate, dorsal spots and stripes on pro-, meso-, metanotum, marginal spots on $1-6^{\text {th }}$, stripes on $7-8^{\text {th }}$ tergites, siphunculi brown; cauda light brownish.

Table 1. Comparison of some morphological characteristics of some familiar species from Xerobion genus. Таблица 1. Сопоставление некоторых морфологических признаков обычных видов рода Xerobion.

\begin{tabular}{|l|c|c|c|}
\hline \multicolumn{1}{|c|}{ Characters/Species } & X. cinae & X. artemisiae & X. terraealbae \\
\hline Third antennal segment/Fourth antennal segment & $1.3-2.0$ & $1.7-1.8$ & 1.7 \\
\hline Third antennal segment/Sixth antennal segment & $0.7-1.0$ & 1.4 & $1.0-1.1$ \\
\hline Third antennal segment/Processus terminalis & $1.7-2.8$ & $3.0-3.2$ & 2.8 \\
\hline Processus terminalis/Base of Sixth antennal segment & $0.5-0.7$ & $0.7-0.8$ & 0.7 \\
\hline Siphunculi/ Body length & $0.033-0.043$ & 0.027 & 0.033 \\
\hline Siphunculi/ Cauda & $0.5-0.8$ & 0.8 & $1.0-1.25$ \\
\hline Ultimate rostral segment/Second segment of hind tarsus & $1.20-1.45$ & $1.23-1.25$ & 1.25 \\
\hline Frontal hairs length/Basal diameter of third antennal segment & $1.8-2.5$ & $1.6-2.3$ & $1.8-2.1$ \\
\hline Quantity of hairs on cauda & $14-22$ & $10-18$ & $13-18$ \\
\hline
\end{tabular}


HOST PLANT. Artemisia (s.str.) annua L., A. (Seriphidium) compacta Fisch. et DC., A. (S.) cina Berg., A. (S.) gurganica Krasch., A. (S.) ferganensis Krasch., A. (S.) halophila Krasch., A. (S.) heptapotamica Poljak., A. (S.) lercheana Web., A. (S.) leucodes Schrenk, A. (S.) nitrosa Web., A. (S.) serotina Bge., A. (S.) scopiformis Ledeb., A. (S.) schrenkiana Ledeb., $A$. (S.) sublessingiana (Kell.) Krasch., A. (S.) terrae-albae Krasch., A. (S.) turanica Krasch. (Asteraceae).

BIONOMY. Aphids suck on flowers and shoots, visited by ants.

Xerobion lambersi (Taschev, 1961) stat.rest.

$=X$. tashevella (Eastop et Hille Ris Lambers, 1976) syn. $\mathbf{n}$.

REMARKS. This species has been reduced to synonyms of $X$. cinae [Eastop \& Blackman, 2006]. However, it differs from $X$. cinae by light-green natural color, pale femora (on slides), ratios of ultimate rostral segment to the second segment of hind tarsus (1.00-1.18 in comparison $1.2-1.4)$, siphunculi to cauda length $(0.7-1.0$ versus $0.5-0.9)$, diameter of tubercle on $7^{\text {th }}$ tergite to basal diameter of $3^{\text {rd }}$ antennal segment (1.0-1.5 and 2.0-2.5), length of hairs on 3-6 tergites to basal diameter of $3^{\text {rd }}$ antennal segment (1.6-2.0 against 1.3-1.7) and host plants from different subgenus of Artemisia. Materials from Iran (Alvaz, Artemisia dracunculus) [Barbagallo, 1996], Ukraine [Bozhko, 1976], Moldova [Vereshchagin et al., 1985], Pakistan [Naumann-Etienne \& Remaudiere, 1995] should include to $X$. lambersi

Apterous viviparous female (by 20 specimens from Bulgaria, Iran, Kazakhstan). Body oval, 1.29-1.69. Cuticle reticulated. Frons convex. Frontal setae (0.028-0.036) 1.6-2.2 of basal diameter of $3^{\text {rd }}$ antennal segment. Antennae five- or six-segmented, $0.37-0.47$ of body length. Third segment $1.3-2.0$ of $4^{\text {th }}, 1.9-2.6$ of processus terminalis and $0.70-1.05$ of $6^{\text {th }}$ segment. Processus terminalis $0.56-0.80$ of base of $6^{\text {th }}$ segment. Fourth segment 0.90 1.05 of $5^{\text {th }}$. Secondary rhinariae are on $3^{\text {rd }}((0) 1-7), 4^{\text {th }}$ $((0) 1-3), 5^{\text {th }}(0-2)$ antennal segments. Hairs on $3^{\text {rd }}$ segment (0.011-0.017) $0.7-1.0$ of its basal diameter. Clypeus normal, rostrum reaches behind to middle coxae. Ultimate rostral segment stiletto-shaped, 1.00-1.18 of second segment of hind tarsus, with 2 accessory hairs. Siphunculi very short, volcano-shaped with flanges, about 0.033 0.048 of body length, $0.7-1.0$ of cauda length, $0.55-0.70$ of its maximal width, $0.45-0.55$ of second segment of the hind tarsus. Cauda triangular, $0.40-0.55$ of its basal width, 0.6-0.8 of second segment of hind tarsus, with 14-26 hairs. Marginal tubercles gentle, hemispherical, developed on prothorax, $1^{\text {st }}$ and $7^{\text {th }}$ tergites. Diameter of tubercle on $7^{\text {th }}$ tergite approximately equal to that on $1^{\text {st }}$ one and $1.0-1.5$ of basal diameter of $3^{\text {rd }}$ antennal segment. Hairs on $3-6$ tergites $(0.025-0.034) 1.6-2.0$ of basal diameter of $3^{\text {rd }}$ antennal segment. $8^{\text {th }}$ tergite with (4) 5-6 (7) hairs. Genital plate oval with 2 hairs on disc and 6-8 ones along its posterior margin. Legs normally developed. Trochanter hair of the hind leg (0.028-0.034) $0.65-0.85$ and longest hair on the external side of hind femur $(0.022-0.025) 0.5$ 0.6 of trochantro-femoral suture. First tarsal segments with $3: 3: 2$ hairs.

Color on slide: frons, apices $6^{\text {th }}$ antennal segments, clypeus, $3^{\text {rd }}-4^{\text {th }}$ rostral segments, tarsi, genital plate light-brown; siphunculi brown; cauda pale.

Natural coloration: body light-green or green without wax powder; eyes dark-reddish; siphunculi light-brown.
Alate viviparous female (by 6 specimens). Body oval, $1.22-1.60$. Antennae $0.39-0.49$ of body length. Third antennal segment $1.8-2.2$ of $4^{\text {th }}$. Fourth antennal segment $0.9-1.0$ of $5^{\text {th }}$. Secondary rhinariae are on $3^{\text {rd }}(5-12), 4^{\text {th }}(2-5), 5^{\text {th }}(1-$ 3 ) antennal segments. Siphunculi about $0.034-0.039$ of body length, $0.75-0.95$ of cauda, $0.65-0.95$ of its maximal width. Cauda $0.50-0.55$ of its basal width . Other characters as apterous female.

Color on slide: head, thorax, $1^{\text {st }}, 2^{\text {nd }}$, apices of $6^{\text {th }}$ antennal segments, clypeus, $3^{\text {rd }}-4^{\text {th }}$ segments of rostrum, coxae, trochanters, apices of femora, tarsi, genital plate, some marginal dorsal spots on $1-4^{\text {th }}$ tergites, siphunculi light brownish; cauda pale.

HOST PLANT. Artemisia (Oligosporus) arenaria DC., A. (O.) dracunculus L., A. (O.) marschalliana Spreng., A. (O.) scoparia Waldst. et Kit. (Asteraceae).

BIONOMY. Aphids suck on flowers and shoots, visited by ants.

\section{Xerobion juchnevitchae Smajlova, 1974}

REMARKS. $X$. juchnevitchae Smajl. is unique in this genus. Its ultimate rostral segment is shorter than the second segment of hind tarsus in comparison with other species.

MATERIAL EXAMINED. Paratypes: 11 apterous viviparous females, slide No 179 (old series), Atriplex cana, Central Kazakhstan, Karaganda Area, Zhanaarka district, Koksenghir mountains, Taldymanak river, 13.07.1962, N.E. Smajlova. 1 alate viviparous female, 4 apterous viviparous females, slide No 2585 (old series), Atriplex cana, Eastern Kazakhstan, Semipalatinsk Area, Madeniet small town environs, 31.05.1978, N.E. Smajlova.

Apterous viviparous female (by specimens from type series and other materials). Body oval, 1.17-1.79. Cuticle reticulated. Frons convex. Frontal setae (0.045-0.056) 2.03.0 of basal diameter of $3^{\text {rd }}$ antennal segment. Antennae sixsegmented, $0.51-0.73$ of body length. Third segment (1.45) $1.6-2.0$ of $4^{\text {th }}, 2.8-3.7$ of processus terminalis and 1.10 1.35 of $6^{\text {th }}$ segment. Processus terminalis $0.50-0.65$ of base of $6^{\text {th }}$ segment. Fourth segment $0.86-1.15$ of $5^{\text {th }}$. Secondary rhinariae are on $3^{\text {rd }}(0-2)$ antennal segment only. Hairs on $3^{\text {rd }}$ segment $(0.022-0.034) 1.2-1.6$ of its basal diameter. Clypeus normal, rostrum reaches behind to middle coxae. Ultimate rostral segment stumpy, pointed, $0.8-0.9$ of second segment of hind tarsus, with 2 accessory hairs. Siphunculi very short, volcano-shaped with flanges, about 0.044 0.050 of body length, $0.57-0.72$ of cauda length, $0.45-$ 0.65 of its maximal width, $0.40-0.55$ of second segment of the hind tarsus. Cauda triangular, $0.40-0.55$ of its basal width, $0.70-0.85$ of second segment of hind tarsus, with 15-25 hairs. Marginal tubercles gentle, hemispherical, developed on prothorax, $1^{\text {st }}$ and $7^{\text {th }}$ tergites. Diameter of tubercle on $7^{\text {th }}$ tergite $(0.028-0.039) 0.8-0.9$ of $1^{\text {st }}$ one and $1.3-$ 1.8 of basal diameter of $3^{\text {rd }}$ antennal segment. Hairs on 3-6 tergites $(0.030-0.050) 1.5-2.5$ of basal diameter of the $3^{\text {rd }}$ antennal segment. $8^{\text {th }}$ tergite with $6-10$ hairs. Genital plate oval with $2-4$ hairs on disc and $8-14$ ones along its posterior margin. Legs normally developed. Trochanter hair of the hind leg (0.045-0.050) $0.9-1.0$ and longest hair on the external side of hind femur $(0.039-0.045) \quad 0.8-0.9$ of trochantro-femoral suture. First tarsal segments with $3: 3: 2$ hairs.

Color on slide: head, $1^{\text {st }}, 2^{\text {nd }}, 5^{\text {th }}, 6^{\text {th }}$ antennal segments (sometimes all antennae), clypeus, $3^{\text {rd }}-4^{\text {th }}$ segments of rostrum, coxae, trochanters, femora, bases and apices of tibiae, tarsi, genital plate, dorsal spots and stripes on pro-, meso-, metathorax, 7-8 $8^{\text {th }}$ abdominal tergites brownish; siphunculi brown; cauda pale or light brownish. 
Natural coloration: body dark-green or brownish with wax powder; eyes dark-reddish; siphunculi blackish.

Alate viviparous female (by 1 specimen). Body oval, 1.81. Secondary rhinariae are only on $3^{\text {rd }}(9)$ antennal segments. Ultimate rostral segment 0.75 of second segment of hind tarsus. Siphunculi about 0.035 of body length. Cauda 0.61 of its basal width, 0.46 of second segment of hind tarsus. Other characters as apterous female.

Color on slide: head, thorax, antennae, clypeus, $3^{\text {rd }}-4^{\text {th }}$ segments of rostrum, coxae, trochanters, femora, bases and apices of tibiae, tarsi, genital plate, dorsal spots and stripes on pro-, meso-, metathorax, marginal spots on 1-6 $6^{\text {th }}$ , stripes on $7-8^{\text {th }}$ tergites, siphunculi brown; cauda light brownish.

HOST PLANT. Atriplex cana C.A. Mey. (Chenopodiaceae).

BIONOMY. Aphids suck on lower side of leafs, visited by ants.

ETYMOLOGY. This species is named after Lydia Juchnevitch. Therefore the correct species name to be $X$. juchnevitchae, but not X. juchnevitchi.

Xerobion caspicae (Bozhko, 1963)

$=X$. brutii $($ Barbagallo, 1996) syn.n.

$=X$. georgii (Mier et Nieto, 1991) syn.n.

I have examined a specimen of the paratype from collection of M.P. Bozhko. Some of the measurements and proportions: frontal and dorsal hairs $(0.019) 0.7$ of basal diameter of $3^{\text {rd }}$ antennal segment, trochanter hair of the hind leg (0.019) 0.25 of trochantro-femoral suture, u. r. s. $0.17,2 \mathrm{~s}$. h. t. 0.15 , siphunculi 0.063 of body length are added to the original description by me. Specimen from Kazakhstan on Artemisia sp. (collection of Institute of Zoology, Almaty) have same characteristics and 16 hairs on the cauda. Table 2 shows the comparative values for 9 main morphological traits in three species Xerobion with short frontal hairs, living on plants of the subgenus Oligosporus from genus Artemisia. We have almost complete overlap of the values of these morphological characters in fact. Thus, these characteristics leave no doubt that $X$. brutii (Barbagallo, 1996) and X. georgii (Mier et Nieto, 1991) are new synonyms of $X$. caspicae (Bozh.).
KEY TO APTEROUS VIVIPAROUS FEMALES OF XEROBION NEVSKY, 1928

1 Aphids with thick wax powder. Ultimate rostral segment elongated, more 1.5 of second segment of hind tarsus. 2

- Aphids with or without wax powder. Ultimate rostral segment elongated, stumpy or stiletto-shaped, no more 1.45 of second segment of hind tarsus. ....................... 6

2 Marginal tubercles on $1^{\text {st }}$ and $7^{\text {th }}$ abdominal tergites only. Secondary rhinariae on $3^{\text {rd }}-5^{\text {th }}$ antennal segments in norm. On Helichrysum armoenium. Iran. $X$ album (Remaudière et Davatchi, 1959)

- Marginal tubercles on $1^{\text {st }}-4^{\text {th }}, 7^{\text {th }}$ abdominal tergites. Secondary rhinariae are absent. ......................................... 3

3 Ultimate rostral segment 1.9-2.3 of second segment of hind tarsus. Processus terminalis $0.8-1.0$ of base of $6^{\text {th }}$ antennal segment. $8^{\text {th }}$ tergite with 4 hairs. On Kochia prostrata, K. scoparia. Spain, Italy, Ukraine, Russia (North Caucasus, Lower Volga), Azerbaijan, Pakistan, Uzbekistan, Kazakhstan, West China (Xinjiang). .......... ............................ X. eriosomatinum Nevsky, 1928

- Ultimate rostral segment no more 1.75 of second segment of hind tarsus. $8^{\text {th }}$ tergite with $2-3$ hairs....................... 4

$43^{\text {rd }}$ antennal segment $0.95-1.00$ of $6^{\text {th }}$ one and $2.2-2.6$ of processus terminalis. Siphunculi $0.9-1.0$ of cauda. Cauda with 8-10 hairs. On Cichorium intybus. Ukraine.......... X. inthybi Bozhko, 1963

- $3^{\text {rd }}$ antennal segment $0.76-0.92$ of $6^{\text {th }}$ one and $1.6-2.0$ of processus terminalis. Siphunculi $0.45-0.65$ of cauda. Cauda with $12-18$ hairs.

5 Processus terminalis $0.9-1.2$ of base of $6^{\text {th }}$ antennal segment. Siphunculi $0.45-0.55$ of cauda. Cauda $0.8-1.0$ of second segment of hind tarsus. On Camphorosma spp. Bulgaria, Kazakhstan, West China (Xinjiang). .............. X. camphorosmae (Taschev, 1961)

- Processus terminalis $0.75-1.00$ of base of $6^{\text {th }}$ antennal segment. Siphunculi $0.60-0.65$ of cauda. Cauda 1.0-1.1 of second segment of hind tarsus. On Helichrysum arenarium. Kazakhstan............................ X. barsukense sp. n.

6 Ultimate rostral segment stumpy, $0.75-0.90$ of second segment of hind tarsus. On Atriplex cana. Kazakhstan. X. juchnevitchae Smajlova, 1974

Table 2. Comparison of some morphological characteristics of Xerobion species with short frontal hairs. Таблица 2. Сравнение некоторых морфологических признаков видов рода Xerobion species с короткими лобными волосками.

\begin{tabular}{|l|c|c|c|}
\hline \multicolumn{1}{|c|}{ Characters/Species } & X. caspicae & X. georgii & X. brutii \\
\hline Third antennal segment/Fourth antennal segment & $1.3-1.5$ & $1.5-1.8$ & $1.3-1.5$ \\
\hline Third antennal segment/Sixth antennal segment & $0.7-1.0$ & $0.6-1.0$ & $0.6-1.0$ \\
\hline Third antennal segment/Processus terminalis & $2.6-3.2$ & $2.6-3.3$ & $1.7-2.1$ \\
\hline Processus terminalis/Base of Sixth antennal segment & $0.4-0.6$ & $0.5-0.7$ & $0.6-0.8$ \\
\hline Siphunculi/ Body length & $0.030-0.063$ & $0.033-0.053$ & $0.038-0.060$ \\
\hline Siphunculi/ Cauda & $0.7-0.9$ & $0.6-0.8$ & $0.7-1.0$ \\
\hline Ultimate rostral segment/Second segment of hind tarsus & $1.1-1.2$ & $1.05-1.20$ & $1.10-1.25$ \\
\hline Frontal hairs length/Basal diameter of third antennal segment & $0.7-0.9$ & 0.7 & $0.7-1.1$ \\
\hline Quantity of hairs on cauda & $12-16$ & $16-26$ & $15-18$ \\
\hline
\end{tabular}


- Ultimate rostral segment elongated, stumpy or stilettoshaped, equal or longer of the second segment of hind tarsus. No on Chenopodiaceae.

7 Marginal tubercles on $1^{\text {st }}$ and $7^{\text {th }}$ abdominal tergites only.

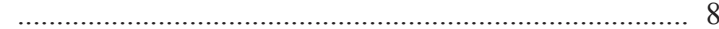

- Marginal tubercles on $1^{\text {st }}-4^{\text {th }}, 7^{\text {th }}$ abdominal tergites. 15

8 Frontal hairs $0.7-1.0$ of basal diameter of the $3^{\text {rd }}$ antennal segment. On Artemisia (Oligosporus) campestris, A. (O.) variabilis, A. caspica. Spain, Italy, Ukraine, Kazakhstan. X. caspicae (Bozhko, 1963)

- Frontal hairs no lesser 1.5 of basal diameter of the $3^{\text {rd }}$ antennal segment. powder. Ultimate rostral segment stumpy, elongated or stiletto-shaped, $1.00-1.18$ of second segment of hind tarsus.

.. 10

- Ultimate rostral segment stiletto-shaped, 1.2-1.4 of second segment of hind tarsus...................................... 13

10 Frontal hairs $1.5-2.0$ of basal diameter of the $3^{\text {rd }}$ antennal segment. .. 11

- Frontal hairs 2.0-3.5 of basal diameter of the $3^{\text {rd }}$ antennal segment.

$113^{\text {rd }}$ antennal segment $0.6-0.7$ of $6^{\text {th }}$ one. Processus terminalis $0.95-1.10$ of base of $6^{\text {th }}$ antennal segment. On Hyalea pulchella. Turkmenistan, Southern Kazakhstan. X. zoijae (Nevsky, 1937)

- $3^{\text {rd }}$ antennal segment $0.7-1.0$ of $6^{\text {th }}$ one. Processus terminalis $0.56-0.80$ of base of $6^{\text {th }}$ antennal segment. On Artemisia (Oligosporus) dracunculus, A. (O.) marschalliana, A. (O.) scoparia, A. (O.) tomentella. Bulgaria, Moldova, Ukraine, Turkey, Iran, Pakistan, Afghanistan, Kazakhstan. ..................... X. lambersi (Taschev, 1961)

$123^{\text {rd }}$ antennal segment $0.8-0.9$ of $6^{\text {th }}$ one and 2.2 of processus terminalis. Ultimate rostral segment stumpy, pointed. Siphunculi $0.050-0.056$ of body length. Secondary rhinariae are absent. Cauda with 11-16 hairs. On Artemisia desertorum. Russia (Far East).

X. amurensis (Pashtshenko, 1992)

- $3^{\text {rd }}$ antennal segment $1.0-1.4$ of $6^{\text {th }}$ one and 2.9-3.9 of processus terminalis. Ultimate rostral segment stilettoshaped. Siphunculi $0.040-0.044$ of body length. Secondary rhinariae on $3^{\text {rd }}-4^{\text {th }}$ antennal segments. Cauda with 19-22 hairs. On Cousinia perovskiensis, Cirsium arvense. Kazakhstan. ......................... X. compositae $\mathbf{s p .} \mathbf{n}$.

13 More large. Frontal hairs 1.5-2.5 of basal diameter of the $3^{\text {rd }}$ antennal segment. Secondary rhinariae in norm on $3^{\text {rd }}$ $-4^{\text {th }}$ antennal segments, rarely on $5^{\text {th }}$ one. Cauda with 14 24 hairs. On Artemisia (Seriphidium) spp. Iran, India (Kashmir), Turkmenistan, Uzbekistan, Tajikistan, Kyrgyzstan, Kazakhstan, West China (Xinjiang), Russia(Lower Volga, West Siberia). ........ X. cinae (Nevsky, 1928)

- Very small. Frontal hairs 2.5-4.0 of basal diameter of the $3^{\text {rd }}$ antennal segment. Secondary rhinariae rarely on $3^{\text {rd }}-4^{\text {th }}$ antennal segments. Cauda with 8-14(16) hairs......... 14

14 Cauda triangular, $0.055-0.065$ of body length. On Artemisia (Seriphidium) spp. Kazakhstan, West China (Xinjiang). ........................... X. alakuli (Juchnevitsh, 1974)

- Cauda bluntly triangular, $0.045-0.053$ of body length. On Helichrysum arenarium. Kazakhstan. $X$. desertorum sp. $\mathbf{n}$

15 Frontal hairs shorter, no more 1.2 of basal diameter of the $3^{\text {rd }}$ antennal segment.

16

- Frontal hairs longer, no lesser 1.5 of basal diameter of the $3^{\text {rd }}$ antennal segment. .......................................... 17

16 Frontal hairs $1.0-1.2$ of basal diameter of the $3^{\text {rd }}$ antennal segment. $3^{\text {rd }}$ antennal segment $2.0-3.0$ of processus termi- nalis. Processus terminalis $0.45-0.55$ of base of $6^{\text {th }}$ antennal segment. Ultimate rostral segment $1.0-1.2$ of second segment of hind tarsus. On Artemisia (Seriphidium) maritima. Hungary................. X. hortobagyi (Szelegiewicz, 1978)

- Frontal hairs $0.5-0.7$ of basal diameter of the $3^{\text {rd }}$ antennal segment. $3^{\text {rd }}$ antennal segment $1.4-1.9$ of processus terminalis. Processus terminalis $0.7-0.8$ of base of $6^{\text {th }}$ antennal segment. Ultimate rostral segment $1.25-1.40$ of second segment of hind tarsus. On Artemisia (s. str.) absinthium. Hungary, Kazakhstan.

X. pannonica (Szelegiewicz, 1978)

17 Frontal hairs $1.5-1.7$ of basal diameter of the $3^{\text {rd }}$ antennal segment. On Artemisia (Oligosporus) campestris, A. sp. Poland, Latvia, Kazakhstan (north).

X. judenkoi (Szelegiewicz, 1959)

- Frontal hairs $2.5-4.5$ of basal diameter of the $3^{\text {rd }}$ antennal segment. On Artemisia (Seriphidium) herba-alba; Spain. X. blascoi (Prieto et Segovia, 1998)

\section{Conclusions}

The revision of Xerobion Nevsky, 1928 is provided the first time. Three new species are described and three ones are re-described. Five species are recognized as the synonyms. Key to all known species of Xerobion by the apterous viviparous females is compiled.

ACKNOWLEDGEMENTS. I thanks to Georges Remaudière (Museum national d'Histoire naturelle, Paris, France) and Andrey Stekolshchikov (Zoological Institute RAN, Saint Petersburg, Russia) for the opportunity to examine type specimens of some species.

\section{References}

Barbagallo S. 1996. On a new Absinthaphis species living on Artemisia variabilis in Italy (Homoptera, Aphididae) // Bollettino di Zoologia Agraria e di Bachicoltura. Vol.28. No.2. P.99-109.

Blackman R.L., Eastop V.F. 2006. Aphids on the World's Herbaceous Plants and Shrubs. Vol.1-2. John Wiley \& Sons Ltd. Natural History Museum. The Aphids. 1439 pp.

Bozhko M.P. 1963. [Xeromorphic aphids (Homoptera, Aphidoidea) of the steppe zone of Ukraine and considerations about their origin] // Trudy Biologicheskogo Faculteta Kharkovskogo Universiteta. T.36. P.108-143. [in Russian].

Bozhko M.P. 1976. [Aphids of the nutritious plants]. Kharkov: Visha shkola. 131 pp. [in Russian].

Eastop V.F. \& Blackman R.L. 2005. Some new synonyms in Aphididae (Hemiptera: Sternorrhyncha) // Zootaxa. No.1089. P.1-36.

Garcia Prieto F., Sanchis Segovia A. 1998. Aphis (Absinthaphis) blascoi sp.n. living on Artemisia herba-alba in Los Monegros (Spain) // Aphids in natural and managed ecosystems. Leon. P.345-349.

Ivanovskaja O.I. 1960. [Xerobionts of Aphidina (Homoptera) subtribe of Soviet Union] // Trudy Biologicheskogo Instituta SO AN USSR, Vyp.6. P.87-154. [in Russian].

Juchnevitsh L.A. 1974. [New aphids species (Homoptera, Aphidinea) from Southern-Eastern Kazakhstan] // Trudy Instituta Zoologii AS Kaz. SSR. T.35. P.51-55. [in Russian].

Kadyrbekov R.Kh. 1995. [About status of two aphids species (Homoptera, Aphidinea) described by L.A. Juchnevitsh]// Selevinia. Vol.3. No.2. P.29-31. [in Russian].

Kadyrbekov R.Kh. 2001. Contribution to the systematic of the xerobiont supraspecific taxa from subtribe Aphidina (Homoptera, Aphididae) // Tethys Entomological Research. Vol.3. P.91-99. 
Mier Durante M.P., Nieto Nafria J.M. 1991. Aphis (Absinthaphis) georgii n.sp. (Homoptera, Aphididae), a new aphid living on Artemisia (Compositae) in Spain // Entomologica Basiliensia. Vol.14. P.9-21.

Naumann-Etienne K., Remaudiere G. 1995. A comment preliminary checklist of aphids (Homoptera: Aphididae) of Pakistan and their host plants // Parasitica. Vol.51. No.1. P.3-61.

Nevsky V.P. 1929. [A plant-lice of the Middle Asia] // Trudy Uzbekskoy Opytnoy Stantsyi Zashchity Rasteniy. No.16. P.1424. [in Russian]

Nevsky V.P. 1937. [To the knowledge of aphids from the Middle Asia] // Bulletin Sredneasiatskogo Gosudarstvennogo Universiteta. T.22. P.291-298. [in Russian].

Remaudière G., Davatchi A. 1959. Sur deux Aphididae (Hom.) nouveaux vivant en Iran sur Helichrysum et Centaurea // Revue de Pathologie vegetale et d'entomologie agricole de France.
Vol.38. No.3. P.201-210.

Remaudière G., Remaudière M. 1997. Catalogue des Aphididae du monde. Paris: INRA. 473 pp.

Smajlova N.E. 1974. [New subspecies and species of aphids (Homoptera, Aphidoidea) from Central Kazakhstan] // Trudy Instituta Zoologii AN Kaz. SSR. T.35. P.43-50. [in Russian].

Szelegiewicz H. 1959. Zwei neue Blattlausarten (Hom. Aphididae) aus Polen // Annales Zoologici. Vol.18. No.1. P.1-10.

Szelegiewicz H. 1978. Three new aphid species (Hom., Aphidoidea) from Artemisia in Hungary // Acta Zoologica Academie Science Hungary. Vol.24. No.1-2. P.211-218.

Taschev D.G. 1961/1962. Zwei neue Blattlausarten der gattung Brachyunguis Das aus Bulgarien (Hom., Aphid.) // Annuaire de L’Universite de Sofia. Bd.56. S.191-203.

Vereshchagin B.V., Andreev A.V., Vereshchagina A.V. 1985. [Aphids of Moldavia]. Kishinev: Shtiinca. 157 pp. [in Russian] 